\title{
KOMENTARZ NA KANWIE UCHWAŁY NACZELNEGO SĄDU ADMINISTRACYJNEGO I FPS 1/21 - SĄDOWA KONTROLA INSTRUMENTALNEGO WSZCZĘCIA POSTĘPOWANIA KARNEGO SKARBOWEGO A PRAWO DO SĄDU
}

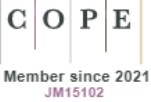

\section{Adam Szymacha* (D), Kamil Rogalski*}

\section{COMMENTARY ON THE BASIS OF THE INSTRUMENTAL INITIATION OF FISCAL PENAL PROCEEDINGS AND THE RIGHT TO COURT OF THE RESOLUTION OF THE SUPREME ADMINISTRATIVE COURT I FPS 1/21 - JUDICIAL CONTROL}

\begin{abstract}
The purpose of the article/hypothesis: The presented article focuses on a new resolution of the Supreme Administrative Court I FPS 1/21. In this resolution an assessment of instrumental initiation of criminal fiscal proceedings in order to suspend the running of the limitation period of a tax liability has been undertaken. The Supreme Administrative Court assessed that administrative courts have the right to examine the legitimacy of initiation of such proceedings. This position is important insofar as it also touches upon the issue of the right to a fair trial, as well as the right to property and legal certainty. The main aim of this article is to check the impact of this resolution on described fundamental rights.

Methodology: This article will use the comparative law method. Especially the case law of different courts will be shown. The dogmatic-legal method will also be used as an auxiliary.

Results of the research: This resolution is crucial for the fundamental right for fail trial. It has also impact on the right to property and principle of legal certainity. It may also be some element that strengthens the rule of law.
\end{abstract}

Keywords: Resolution I FPS 1/21, instrumental initiation of criminal fiscal proceedings, tax liabilities, right to fair trial, right to property, legal certainity principle, suspension of the limitation period for tax liability.

JEL Class: K34, K38.

\footnotetext{
* Mgr, Absolwent Wydziału Prawa i Administracji oraz Wydziału Zarządzania, Uniwersytet Łódzki, e-mail: adam.szymacha88@gmail.com.

** Student V roku Wydziału Prawa i Administracji, Uniwersytet Łódzki, e-mail: kamil.b.rogalski@gmail.com.
} 


\section{WSTĘP}

Dnia 24 maja 2021 roku została podjęta uchwała Naczelnego Sądu Administracyjnego (dalej NSA) o numerze sygnatury I FPS 1/21. W uchwale tej, podjętej w składzie 7 sędziów, w sprawie dotyczącej sądowej kontroli biegu terminu przedawnienia zobowiązania podatkowego, NSA podjął się oceny czy badanie przesłanek zastosowania przez organy podatkowe przy wydawaniu decyzji podatkowej art. $70 \S 6$ pkt 1 w związku z art. 70c ustawy z dnia 28 sierpnia 1997 r. Ordynacja podatkowa (dalej OP) (Dz.U. 2020, poz. 1325 ze zm.) mieści się w granicach sprawy sądowej kontroli legalności tej decyzji. Uchwała została podjęta na wniosek Rzecznika Małych i Średnich Przedsiębiorców z dnia 18 grudnia 2020 r., zawierającego pytanie: „Czy w świetle art. 1 § 2 ustawy z dnia 25 lipca 2002 r. Prawo o ustroju sądów administracyjnych (Dz.U. 2017, poz. 2188 ze zm.) oraz art. $134 \S 1$ ustawy z dnia 30 sierpnia 2002 r. Prawo o postępowaniu przed sądami administracyjnymi (dalej p.p.s.a.) (Dz.U. 2019, poz. 2325 ze zm.), ocena wszczęcia postępowania karnego skarbowego z punktu widzenia wywołania wyłącznie skutku w postaci wydłużenia postępowania podatkowego poprzedzającego wydanie decyzji podatkowej i w celu nierozpoczęcia albo zawieszenia biegu terminu przedawnienia zobowiązania podatkowego w rozumieniu art. $70 \S 6$ pkt 1 oraz art. 70c ustawy z dnia 29 sierpnia 1997 r. Ordynacja podatkowa mieści się w granicach sprawy sądowej kontroli legalności tej decyzji?". W związku z tak sformułowanym pytaniem zawartym we wniosku treść uchwały jest następująca: „W świetle art. 1 ustawy z dnia 25 lipca 2002 r. Prawo o ustroju sądów administracyjnych oraz art. 1-3 i art. $134 \S 1$ ustawy z dnia 30 sierpnia 2002 r. Prawo o postępowaniu przed sądami administracyjnymi ocena przesłanek zastosowania przez organy podatkowe przy wydawaniu decyzji podatkowej art. $70 \S 6$ pkt 1 w zW. z art. 70c ustawy z dnia 29 sierpnia 1997 r. Ordynacja podatkowa mieści się w granicach sprawy sądowej kontroli legalności tej decyzji”.

Sam wniosek Rzecznika Małych i Średnich Przedsiębiorców jest wynikiem negatywnie ocenianej praktyki organów podatkowych, zgodnie z którą wszczynano postępowanie w sprawie o przestępstwo skarbowe lub wykroczenie skarbowe, tylko z zamiarem doprowadzenia do zawieszenia biegu terminu przedawnienia zobowiązania podatkowego. Jak podkreślił J. Cieplak Zastępca Rzecznika Małych i Średnich Przedsiębiorców, z ustnych motywów uzasadnienia uchwały wynika, że ,sądy administracyjne są uprawnione do oceny czy postępowanie karne skarbowe wszczęte zostało wobec przedsiębiorcy w sposób instrumentalny" (www1). Pierwszym celem niniejszego artykułu jest opisanie tła oraz istotnych elementów problematyki zawieszenia biegu terminu przedawnienia zobowiązania podatkowego za sprawą instrumentalnego wszczęcia postępowania karnego skar- 
bowego. Drugim celem jest wykazanie wpływu badania przez sądy administracyjne instrumentalnego wszczynania takiego postępowania na prawidłową realizację prawa do rzetelnego procesu sądowego.

Pierwsza hipoteza brzmi: opisywana uchwała stanowi zwieńczenie wcześniejszego orzecznictwa sądów administracyjnych, będąc zarazem jego logicznym i spójnym dopełnieniem.

Druga hipoteza brzmi: opisywana uchwała wywiera dalekosiężny skutek w postaci przywrócenia podatnikom prawa do rzetelnego procesu sądowego gwarantowanego przez Konstytucję i Europejską Konwencję Praw Człowieka. Prawo to zostało podatnikom odebrane poprzez rzeczywiste działania organów państwowych.

\section{PRZEDAWNIENIE ZOBOWIAZZANIA PODATKOWEGO W ŚWIETLE PRZEPISÓW ORDYNACJI PODATKOWEJ}

Zgodnie $\mathrm{z}$ art. $70 \S 1$ OP zobowiązanie podatkowe przedawnia się $\mathrm{z}$ upływem 5 lat, licząc od końca roku kalendarzowego, w którym upłynął termin płatności podatku. Sens instytucji przedawnienia opisuje orzecznictwo NSA. W wyroku II FSK 513/10 stwierdzono: ,instytucja przedawnienia ma na celu uregulowanie sytuacji prawnej przeciągającego się w czasie stosunku prawnopodatkowego, nawet kosztem niewykonania zobowiązania" (Wyrok NSA z 26.09.2011 r., II FSK 513/10, POP 2012, Nr 1, poz. 1). W uchwale pełnej Izby Finansowej II FPS 4/13 wypowiedział się co do skutków upływu terminu przedawnienia. Zgodnie z tezą uchwały ,po upływnie terminu przedawnienia nie jest dopuszczalne prowadzenie postępowania podatkowego i orzekanie o wysokości zobowiązania podatkowego, które wygasło przez zapłatę" (Uchwała pełnej Izby Finansowej NSA z 29.09.2014 r., II FPS 4/13). Jednak takie ujęcie spotyka się z krytyką w doktrynie. H. Dzwonkowski zauważa, że po upływie przedawnienia można owszem prowadzić nadal postępowanie, byleby obniżać, a nie podwyższać zobowiązanie. Przedawnieniu ulega zatem tylko prawo organu podatkowego do podwyższania zobowiązania podatkowego (Dzwonkowski, 2020).

Art. 70 OP dotyczy przedawnienia wszystkich zobowiązań, zarówno tych wymierzonych deklaracją, jak i tych wymierzonych decyzją (Dzwonkowski, 2020). Ta instytucja daje podatnikom gwarancję stabilności ich sytuacji prawnej, to znaczy że ich sytuacja prawna nie ulegnie zmianie (Babiarz, 2019: 474). W okresie przedawnienia prawnie istotne są dwa czynniki: termin oraz obowiązywanie decyzji. W przypadku gdy decyzję korygującą wydano w okresie przedawnienia, a należność wierzyciela publicznoprawnego została zaspokojona (poprzez zapłatę bądź egzekucję), należy stwierdzić brak przedawnienia zobowiąza- 
nia podatkowego. W przypadku odmiennym, gdy w tym okresie nie nastąpi korekta wymiaru, należy stwierdzić przedawnienie. Instytucji przedawnienia nie należy zatem wiązać z samym tylko upływem czasu (Dzwonkowski, 2020).

Przesłanką przedawnienia nie jest też moc prawa, ale raczej niewykonanie obowiązków, zależących od wiedzy i woli określonych podmiotów. Przedawnienie skutkuje wygaśnięciem zobowiązania podatkowego. Sama zapłata nie powoduje przedawnienia, gdyż zapłata uchyla tylko pewne uprawnienia wierzyciela, takie jak obowiązek zapłaty, w całości lub w części (Dzwonkowski, 2020). Przedawnienie to likwidacja szerszych obowiązków, gdyż oprócz obowiązku zapłaty, wygasa także prawo podwyższania zobowiązania w stosunku do kwoty zadeklarowanej (prawo korekty). Dokonanie zapłaty kwoty wynikającej z deklaracji powoduje wygaśnięcie części zobowiązania wynikającej z samowymiaru, nie zaś zaległość wynikająca z decyzji korygującej. Poprzez dokonanie zapłaty wygasa jedynie zapłacona kwota zobowiązania, zaś przez przedawnienie wygasa także uprawnienie organu do podwyższenia tego zobowiązania. Zobowiązanie podatkowe może zatem wygasnąć w całości albo w części (Dzwonkowski, 2020). Mechanizm zawarty $\mathrm{w}$ art. 70 OP polega na tym, że poprzez przedawnienie może wygasnąć powinność zapłaty, albo prawo korekty deklaracji (Dzwonkowski, 2020).

\section{ZAWIESZENIE BIEGU PRZEDAWNIENIA ZOBOWIAZZANIA PODATKOWEGO}

\section{Z ART. 70 § 6 PKT 1}

Art. $70 \S 6$ pkt 1 OP stanowi przesłankę zawieszenia biegu przedawnienia zobowiązania podatkowego. Zgodnie $\mathrm{z}$ jego treścią bieg terminu przedawnienia zobowiązania podatkowego nie rozpoczyna się, a rozpoczęty ulega zawieszeniu, z dniem wszczęcia postępowania w sprawie o przestępstwo skarbowe lub wykroczenie skarbowe, o którym podatnik został zawiadomiony, jeżeli podejrzenie popełnienia przestępstwa lub wykroczenia wiąże się z niewykonaniem tego zobowiązania. Przepis ten budzi uzasadnione kontrowersje w doktrynie i wśród praktyków prawa podatkowego (Dzwonkowski, 2020; Nita, 2018: 165).

Po pierwsze wspomnieć należy, że w doktrynie zwraca się uwagę na niefortunną konstrukcję tej normy prawnej. Wskazuje się tutaj na relację między prawem karnym a podatkowym. Przedmiotem procedury podatkowej jest co do zasady wymiar, zabezpieczenie i wykonywanie zobowiązań o charakterze podatkowym. Natomiast przedmiotem postępowania karnego jest ustalenie winy sprawcy, wymiar kary, a w postępowaniu karnym wykonawczym także wykonanie kary. $\mathrm{Z}$ tego już wynika, że odmienne cele przyświecają tym postępowaniom.

Przesłanka wszczęcia postępowania w sprawie karnej skarbowej to najczęściej uszczuplenie bądź narażenie na uszczuplenie należności publicznoprawnej. 
Najczęściej wszczęcie postępowania o charakterze karno-skarbowym jest kwestią wtórną w stosunku do wyniku postępowania podatkowego. Zwykle to kwestia wymiaru i wykonywania zobowiązań będzie czynnikiem inicjującym dopiero postępowanie karne. Innymi słowy ustalenie odpowiedzialności karnej skarbowej jest najczęściej uzależnione od wyniku postępowania podatkowego. Zatem zarówno swoistość obu działów prawa, jak i wtórność postępowania karnoskarbowego wobec postępowania podatkowego poddają w wątpliwość regulację, zgodnie z którą wszczęcie postępowania o charakterze karnym, wpływa negatywnie na bieg terminu przedawnienia zobowiązania podatkowego (Dzwonkowski, 2020).

Nie każde jednak wszczęcie postępowania karnego skarbowego zawiesza bieg terminu przedawnienia zobowiązania podatkowego. W wyroku II FSK 1488/15 NSA stwierdził, że „,bieg terminu przedawnienia zobowiązania podatkowego nie uległ $\mathrm{w}$ sprawie zawieszeniu $\mathrm{z}$ uwagi na wszczęcie postępowania w sprawie o przestępstwo skarbowe, ponieważ - w zakresie, w jakim błędnie zakwalifikowano postępowanie skarżącego jako przestępstwo skarbowe - nie istniał realny związek pomiędzy wszczęciem dochodzenia a niewykonaniem tego zobowiązania. Związek ten miał charakter jedynie pozorny i formalny; wynikał wyłącznie z wadliwego ustalenia wysokości zarzucanego uszczuplenia dochodów Skarbu Państwa" (Wyrok NSA z 24.11.2016 r., II FSK 1488/15). Sąd Administracyjny jest zatem właściwy do badania, czy zachodzi przesłanka związku postępowania karnoskarbowego, z niewykonaniem zobowiązania podatkowego (Raport: Instrumentalne wszczynanie postępowań karnych skarbowych...).

Po drugie praktyczną konsekwencją takiego ukształtowania zawieszenia biegu terminu przedawnienia jest patologiczna praktyka organów podatkowych, polegająca na instrumentalnym wszczynaniu postępowania karnego skarbowego, tylko w tym celu, aby doprowadzić do zawieszenia biegu terminu. Postępowania o charakterze karnym są wszczynane przedwcześnie w stosunku do podatników, którym zbliża się termin przedawnienia. Zawieszane są w wyniku tego 35 razy częściej, niż inne postępowania karne skarbowe. Z kolei takie postępowania wszczynane $\mathrm{w}$ trakcie postępowania kontrolnego, w sprawie zobowiązania podatkowego przedawniającego się z końcem danego roku, kończą się 2 razy częściej korzystnymi dla oskarżonego orzeczeniami, niż inne postępowania karne i karne skarbowe (Raport: Instrumentalne wszczynanie postępowań karnych skarbowych...). Organy często też wszczynają postępowanie karne skarbowe, w sytuacji nadchodzącego terminu przedawnienia i kiedy w toku postępowania podatkowego decyzje organu I instancji były już uchylane przez organ odwoławczy z uwagi na brak wyjaśnienia okoliczności faktycznych (Strzelec, 2020: 33).

Taka praktyka nie pozostała niezauważona w orzecznictwie sądów administracyjnych. W orzeczeniu I FSK 128/20 NSA stwierdził, że „sąd administracyjny może kontrolować, czy nie doszło do instrumentalnego wykorzystywania art. 70 
$\S 6$ pkt 1 OP ze względu na wszystkie okoliczności sprawy podatkowej, a w szczególności w sytuacji, gdy wykorzystanie tego przepisu związane jest z naruszeniem zasady zaufania do organów podatkowych (art. $121 \mathrm{OP}$ ), czy wywodzonej z prawa unijnego oraz z art. 2 Konstytucji RP zasady uzasadnionych oczekiwań" (Wyrok NSA z dnia 30.07.2020 r., I FSK 128/20). Jednocześnie stwierdzono, że art. 70 $\S 6$ pkt 1 nie w każdym przypadku stanowi podstawę zawieszenia biegu terminu przedawnienia. Należy w każdym przypadku badać okoliczności sprawy, a w przypadku stwierdzenia, że wszczęcie postępowania karnego skarbowego nastąpiło z przekroczeniem zasady zaufania do organów podatkowych, art. $70 \S 6$ pkt 1 nie może być odczytywany jako podstawa zawieszenia biegu terminu przedawnienia zobowiązania podatkowego. Kontrola sądowoadministracyjna powinna obejmować także badanie zasadności wszczęcia postępowania karnego skarbowego (Dźwigała, 2021: 54). Sąd administracyjny podczas badania, czy nie doszło do instrumentalnego wszczęcia postępowania karnego skarbowego, nie narusza kompetencji sądów powszechnych, gdyż to badanie odbywa się jedynie na potrzeby rozpatrywanej sprawy podatkowej.

W tym kontekście nie sposób nie wspomnieć również o wyroku Wojewódzkiego Sądu Administracyjnego (dalej WSA) I SA/Wr 365/19 (Wyrok WSA we Wrocławiu z dnia 22 lipca 2019 r.I SA/Wr 365/19). W tym orzeczeniu, WSA stwierdził, że wszczęte postępowanie karne skarbowe powinno zmierzać do prawomocnego zakończenia postępowania, szczególnie kiedy od tego postępowania uzależniony jest bieg terminu przedawnienia. Bierność organów podatkowych uznano za sprzeczną z zasadą praworządności (art. 7 Konstytucji RP) i zasadą państwa prawa (art. 2 Konstytucji RP). Uznano też, że praktyka sprowadzająca się do tego, że upływ terminu przedawnienia zależy tylko od uznania organu podatkowego i nie podlega żadnej kontroli sądowej, jest nieakceptowalna. Zagraża ona unijnej zasadzie skuteczności, zaś to powoduje $\mathrm{z}$ kolei naruszenie zasady lojalnej współpracy wyrażonej w art. 4 ust. 3 TUE. Narusza również zasadę pewności prawa i nieproporcjonalnie ogranicza wykonywanie prawa własności. Włączając określone konstrukcje karne skarbowe do art. 70 OP zdecydowano o tym, że stały się one elementem prawa podatkowego. W takim razie podlega on ocenie sądu administracyjnego. Organ podatkowy wszczynając postępowanie karne skarbowe w odmiennym celu niż cel tego postępowania, czyli wyłącznie tylko po to, aby zawiesić bieg terminu przedawnienia zobowiązania podatkowego, $\mathrm{w}$ istocie nadużył swoich kompetencji.

W kontekście powyższego wydaje się, że uchwała NSA I FPS $1 / 21$ jest zwieńczeniem pewnej linii orzeczniczej i zarazem odpowiedzią na palący problem praktyki organów podatkowych. Przełoży się ona także na bardziej stabilną wykładnię art. 70 przez sądy administracyjne za sprawą art. 269 p.p.s.a. Zgodnie z jego treścią, jeżeli jakikolwiek skład sądu administracyjnego rozpoznający sprawę nie podziela stanowiska zajętego w uchwale składu siedmiu sędziów NSA, 
przedstawia powstałe zagadnienie prawne do rozstrzygnięcia odpowiedniemu składowi. Linia orzecznicza sądów administracyjnych w tej sprawie powinna zatem ulec ujednoliceniu.

Znaczenie tej uchwały jest jednak głębsze, gdyż dotyka podstaw prawa. Organy władzy publicznej dążyły w istocie do tego, aby wyeliminować instytucję przedawnienia bez uchylania jej przez ustawodawcę. Taki sposób unicestwiania norm prawa trzeba uznać za naganny. Duża skala nadużyć wynika najprawdopodobniej z faktu, że organy nie czują się ograniczone zewnętrzną kontrolą w tym zakresie (Dźwigała, 2021: 56).

Dalej jeszcze, od strony teoretycznoprawnej, istotnym uzasadnieniem dla instytucji przedawnienia zobowiązania podatkowego jest ochrona dłużnika przed nieograniczoną w czasie koniecznością utrzymywania zdolności do uregulowania podatku. Aksjologicznym elementem przedawnienia jest bowiem założenie, iż długo istniejący stan faktyczny powinien być trwały i niewzruszalny, a także jako nacechowany dawnością powinien być uznany prawnie. Ponadto świadomość skutków zaistnienia instytucji przedawnienia ma być czynnikiem dodatkowo motywującym wierzyciela publicznoprawnego do szybkiego i sprawnego dochodzenia i egzekucji należności podatkowych. Podatnik, wraz z upływem dawności, powinien zyskać pewność swojej sytuacji prawnej (Nita, 2018: 161-162).

Przyczyną ukształtowania konsekwencji upływu terminu z art. 70 OP, polegającego na wygaśnięciu skonkretyzowanej powinności jest podległość dłużnika podatkowego kompetencji administracji, co oznacza, że organy występują w tym przypadku w podwójnej roli. Pierwszą jest rola wierzyciela publicznoprawnego, drugą natomiast jest rola instytucji uprawnionej do rozstrzygania w sprawie pomiędzy nim samym, a podmiotem zobowiązanym. Jest to zatem bardzo silna pozycja organu, a instytucja przedawnienia ma ją rekompensować podatnikowi. W przeciwnym razie nic nie ograniczałoby organu przed oddziaływaniem na podatnika w ten sposób, aby przedawnione zobowiązanie podatkowe jednak spełnił (Nita, 2018: 164).

Ta uchwała wychodzi też naprzeciw postulatom doktryny, w której zwracano uwagę także, na naruszenie praw fundamentalnych poprzez brak badania zasadności zastosowania jednej z przesłanek prowadzących do zawieszenia biegu terminu zobowiązania podatkowego. Konieczność badania skuteczności zawieszenia biegu terminu przedawnienia $\mathrm{z}$ art. $70 \S 6 \mathrm{pkt} 1$ wynika $\mathrm{z}$ prawa do rzetelnego procesu, wywodzonego z art. 45 ust. 1 Konstytucji RP, art. 47 Karty Praw Podstawowych UE, a także art. 6 Europejskiej Konwencji o Ochronie Praw Człowieka i Podstawowych Wolności (Strzelec, 2020: 29). Praktyka organów podatkowych godzi zatem $\mathrm{w}$ prawa podstawowe. 
Wprawdzie prawo unijne ma w tym przypadku ograniczone zastosowanie ${ }^{1}$, jednakże wtedy gdy sądy krajowe badają zgodność z prawami podstawowymi działań organów krajowych, a działanie państw członkowskich nie jest w pełni określone przepisami unijnymi, wtedy organy i sądy krajowe posiadają uprawnienie, aby stosować krajowe standardy ochrony praw fundamentalnych. Warunkiem stosowania krajowych standardów jest to, aby nie były one niższe od standardu ochrony przewidzianego przez Kartę, a także aby nie podważały pierwszeństwa, jednolitości i skuteczności prawa Unii (Wyrok TSUE w sprawie C-617/10 Åkerberg Fransson przeciwko Åklagaren, ECLI:EU:C:2013:105).

Konstytucyjne prawo do sądu wywodzone z art. 45 Konstytucji RP, w tym wymóg sprawiedliwości procesu czyni koniecznym przeprowadzenie procesu na podstawie ściśle określonych procedur uwzględniających zasadę równości stron postępowania (Kowalski, 2019: 297). Zgodnie z art. 32 p.p.s.a. W postępowaniu w sprawie sądowoadministracyjnej stronami są skarżący oraz organ, którego działanie, bezczynność albo przewlekłe prowadzenie postępowania jest przedmiotem skargi. Jednocześnie organ, jako strona postępowania ma pozycję równorzędną w stosunku do skarżącego i ma takie same uprawnienia procesowe (Kowalski, 2019: 367). Uchwała NSA I FPS 1/21 ma zatem też to znaczenie, że przywraca konstytucyjne prawo do sądu, w tym sensie że kończy z uprzywilejowaniem organów podatkowych $\mathrm{w}$ procesie sądowoadministracyjnym. Brak badania zasadności wszczęcia postępowania karnego skarbowego, rzutującego na istotę sprawy umożliwiał $\mathrm{w}$ istocie organom osiągnięcie uprzywilejowanej pozycji procesowej.

\section{PRAWO DO SĄDU WYRAŻONE W ORZECZNICTWIE EUROPEJSKIEGO TRYBUNAŁU PRAW CZtOWIEKA}

Dopuszczalność, a nawet konieczność badania przez sądy zasadności stawiania obywatelowi zarzutu i formowania przeciw niemu oskarżenia została podkreślona przez Europejski Trybunał Praw Człowieka (dalej ETPC) między innymi w wyroku 6903/75 z 27 lutego 1980 r. (Wyrok ETPC 6903/75 w sprawie Deweer przeciwko Belgii, ECLI:CE:ECHR:1980:0227JUD000690375). Trybunał wskazał tu-

\footnotetext{
${ }^{1}$ Prawa gwarantowane Kartą mają zastosowanie m.in. do państw członkowskich tylko w takim zakresie, w jakim stosują one prawo Unii. W zainteresowaniu tego artykułu mogą być zatem sprawy związane z dyrektywami dotyczącymi podatków pośrednich. Precyzowanie pojęcia zastosowania Karty nastąpiło później w sprawie C-617/10 Åkerberg Fransson przeciwko Åklagaren (ECLI:EU:C:2013:105), w którym stwierdzono, że „,poszanowanie praw podstawowych chronionych na mocy karty jest zatem konieczne, w sytuacji gdy przepisy krajowe mieszczą się w zakresie zastosowania prawa Unii. Nie mogą więc występować sytuacje podlegające prawu Unii, w których wspomniane prawa podstawowe nie miałyby zastosowania. Natomiast jeżeli stan prawny nie jest objęty zakresem zastosowania prawa Unii, Trybunał nie jest właściwy do jego oceny” (pkt 21 i 22).
} 
taj niezwykle istotną rolę prawa do rzetelnego procesu jako elementu demokratycznego państwa prawnego, wskazując że przepis artykułu 6 punkt 1 Europejskiej Konwencji Praw Człowieka (dalej EKPC) stanowi o tym, iż każdy ma prawo do zbadania przez sąd zasadności oskarżenia w wytoczonej przeciwko niemu sprawie. Dalej Trybunał odniósł się do oskarżania podmiotów przez organy państwowe, mających na celu wywarcie presji w celu ,zmuszenia” strony do ugody stanowiąc, że takie działanie nie narusza konwencji pod warunkiem przestrzegania wymogów zawartych artykułach 6 i 7 EKPC. Biorąc pod uwagę dotychczasową praktykę organów podatkowych oskarżania obywateli o przestępstwa skarbowe wyłącznie w celu zatrzymania biegu terminu zobowiązania podatkowego należałoby przyjąć, że takie działanie, z jednej strony mające na celu wywarcie presji na podatniku celem wyegzekwowania zobowiązania, a $z$ drugiej strony zamaskowania własnych zaniedbań staje w sprzeczności z zasadą rzetelnego procesu. Oskarżenie bowiem nie opiera się w takiej sytuacji o faktyczne podejrzenie popełnienia przestępstwa zagrożonego karą, a jedynie jest instrumentalnym środkiem nadużywania przez ograny podatkowe prawa.

Ponadto ETPC niejednokrotnie określał jakie przesłanki stanowią o tym, że dana osoba staje się oskarżonym w rozumieniu prawa i w związku z powyższym nabywa uprawnienia podejrzanego/oskarżonego w rzetelnym procesie karnym. Zarówno w wyroku w sprawie połączonych skarg 50541/08, 50571/08, 50573/08 i 40351/09 z 14 grudnia 2014 r. (Wyrok ETPC 0541/08, 50571/08, 50573/08 i 40351/09 w sprawie Ibrachim i inni przeciwko Zjednoczonemu Królestwu, ECLI:CE:ECHR:2016:0913JUD005054108) oraz 21980/04 z 12 maja 2017 r. (Wyrok ETPC 21980/04 w sprawie Simeonovi przeciwko Bułgarii, ECLI:CE:ECHR:2017:0512JUD002198004) zostały wskazane dwa czynniki decydujące o tym, kiedy osoba staje się oskarżona w rozumieniu prawnokarnym. Są to mianowicie $-\mathrm{z}$ jednej strony prawomocne powiadomienie osoby o zarzutach karnych przez właściwy organ oraz z drugiej strony, kiedy sytuacja danej osoby ulega istotnej zmianie w skutek działania podjętego przez władze. W świetle obydwu przesłanek nie ulega wątpliwości, że organ podatkowy, zawiadamiający obywatela o przedstawieniu mu zarzutu działa $\mathrm{w}$ ramach procedur przewidzianych przez kodeks postępowania karnego i tym samym nadaje mu specjalne uprawnienia jako stronie podejrzanej w postępowaniu karnym. Wątpliwość w tym kontekście budzi natomiast druga z tych przesłanek. Należy się tutaj zastanowić, czy podjęte przez organ działania mają faktyczny, a nie tylko formalny wpływ na sytuację obywatela. Zakładając bowiem, że organy podatkowe wszczynają postępowanie wyłącznie $\mathrm{w}$ celu przerwania biegu przedawnienia zobowiązania podatkowego, zakładając przy tym, że postępowanie zostanie umorzone wobec braku znamion czynu zabronionego nie można stwierdzić, że oskarżony o naruszenie prawa jest faktycznie zagrożony sankcją nałożoną w drodze rzetelnego procesu przez 
Sąd. O ile w kwestii formalnej podejrzany/oskarżony każdorazowo stoi przed ryzykiem zapadnięcia wobec niego niekorzystnego wyroku, o tyle w sytuacji instrumentalnego oskarżenia przez organy podatkowe, niepopartego faktycznymi przesłankami karnymi podejrzany/oskarżony w zasadzie powinien odczuć negatywnego rozstrzygnięcia wobec niego. Taka sytuacja budzi poważną wątpliwość w zakresie realizacji prawa do rzetelnego procesu, bowiem już na etapie podjęcia przez organy podatkowe pierwszych działań w ramach czynności wykrywczych postępowanie obarczone jest wadą bezzasadności. Należałoby więc przyjąć, że w takiej sytuacji mamy do czynienia $\mathrm{z}$ nadużyciem prawa, a tym samym z naruszeniem zarówno zasady zaufania obywatela do państwa, jak i prawa do rzetelnego procesu.

W wyroku w sprawie połączonych skarg 5100/71, 5101/71, 5102/71, 5354/72, 5370/72 z 8 czerwca 1976 r. (Wyrok ETPC 5100/71, 5101/71, 5102/71, 5354/72, 5370/72 w sprawie Engel i inni przeciwko Niderlandom, ECLI:CE:ECHR:1976:1123JUD000510071) Trybunał określił swojego rodzaju „test" służący badaniu, czy skierowanie wobec podmiotu prawa oskarżenie może zostać uznanie za oskarżenie w rozumieniu karnym. Tak więc aby stwierdzić, czy oskarżenie ma charakter karny należy w pierwszej kolejności ustalić czy przepis na podstawie którego dokonujemy tej czynności mieści się w zakresie prawa karnego. Jest to jednakże wyłącznie czynność wstępna, której wykluczenie powodowałoby upadek „karności” formowanego oskarżenia już na samym początku. Kolejną z przesłanek, która jest w uznaniu Trybunału znacznie ważniejsza, jest zbadanie charakteru samego czynu, celem rozważenia, czy faktycznie mieści się ono w przedmiocie oskarżenia. I wreszcie kolejną z badanych przesłanek powinno być zbadanie surowości kary, jaka może zostać orzeczona wobec osoby. Przy zastosowaniu powyższych kryteriów stawianie zarzutów przez organy podatkowe bezwzględnie zdaje powyższy test wyłącznie w zakresie pierwszego ze wskazanych etapów. Gdy bowiem przejdziemy do drugiej części, wówczas sąd badający zasadność oskarżenia na podstawie art. 6 ETPC może poddać w wątpliwość to, czy zarzucany podatnikowi czyn jest faktycznym naruszeniem norm określających granice przestępstw i wykroczeń skarbowych. Wynika to z faktu, iż organ dokonujący oskarżenia wyłącznie z zamiarem przerwania okresu przedawnienia zobowiązania nie posiada faktycznych, mocnych argumentów procesowych świadczących o konieczności ukarania obywatela. Trzeci punkt testu również zdaje się wykluczać zasadność oskarżenia, bowiem o ile sensie formalnym sam fakt prawomocnego oskarżenia kogokolwiek o popełnienie przestępstwa lub wykroczenia skarbowego rodzi zagrożenie surową karą, o tyle biorąc pod uwagę faktyczne czyny osoby oskarżonej, a w zasadzie ich brak w chwili oskarżenia, należy stwierdzić, że w rzeczywistości takie zagrożenie nie istnieje. To po raz kolejny konstytuuje wniosek, w myśl którego zastosowanie instrumentalnego oskarżenia narusza prawo do rzetelnego procesu określone artykułem 6 EKPC, a tym samym każdorazowo powinno podlegać badaniu przez sąd. 


\section{PODSUMOWANIE}

Zważywszy na powyższe, można sformułować kilka wniosków. Pierwszym z nich jest to, że uchwała NSA I FPS 1/21 stanowi zwieńczenie pewnej wykładni, która kształtowała się w sądach administracyjnych. Drugim wnioskiem jest to, że uchwała ta z pewnością przyczyni się do ujednoliceni orzecznictwa sądów administracyjnych, a co za tym idzie także do zwiększenia pewności prawa.

Najważniejsze jednak w ocenie autorów jest to, że ta uchwała może przyczynić się do przywrócenia obywatelom podstawowego prawa do sądu. O ile wcześniej obywatel mógł być tego prawa pozbawiony, gdyż sąd administracyjny mógł nie uznać swojej właściwości przy badaniu zasadności wszczęcia postępowania karnego skarbowego, to teraz taki scenariusz wydaje się bardziej odległy. Tym samym podatnikom przywrócono realną instytucję przedawnienia zobowiązania podatkowego. Wcześniej organy mogły w zasadzie swobodnie unicestwiać przedawnienie, poprzez użycie art. $70 \S 6 \mathrm{pkt} 1$ OP. Aktualnie jest bardzo prawdopodobne, że od tej szkodliwej praktyki będą musiały odstąpić, świadome prawdopodobnej kontroli zastosowanych środków przez sąd administracyjny.

Oczywiście temat odbierania podatnikom prawa do rzetelnego procesu sądowego nie został jeszcze wyczerpany. Organy dalej mogą dążyć do unicestwienia instytucji przedawnienia poprzez zastosowanie kolejnych środków egzekucyjnych zgodnie $\mathrm{z}$ art. $70 \S 4 \mathrm{OP}$, jednak zagadnienie to nie mieści się $\mathrm{w}$ granicach tego artykułu. Ważne jest jednak, że podatnicy odzyskali należną im ochronę pozwalającą realizować im inne prawa fundamentalne, takie jak prawo własności. Wyłączenie z kontroli zasadniczego elementu sprawy podatkowej skutkowało bowiem naruszeniem prawa do sądu, ale też dalej pociągało naruszenia prawa własności i zasady pewności prawa oraz budowania zaufania do organów podatkowych. Takie naruszenie wydaje się niedopuszczalne w demokratycznym państwie prawnym i w tym kontekście należy ocenić przedmiotową uchwałę nie tylko jako pozytywną, ale też kluczową dla naprawy poważnej luki w systemie prawa.

\section{BIBLIOGRAFIA}

Babiarz, S. (2019). Rozdział 8. Przedawnienie. W: S. Babiarz, B. Dauter, R. Hauser, A. Kabat, M. Niezgódka Medek, J. Rudowski, red., Ordynacja Podatkowa. Komentarz. Warszawa: Wolters Kluwer.

Dzwonkowski, H. (2020). Art. 70 Termin przedawnienia zobowiązania. W: H. Dzwonkowski, red., Ordynacja Podatkowa. Komentarz. Warszawa: C.H. Beck, www.legalis.pl [dostęp 2.06.2021].

Dźwigała, G. (2021). Instrumentalne wszczęcie postępowania karnego skarbowego a zakres kontroli sądowoadministracyjnej. Przegląd Podatkowy, 1, styczeń.

Kowalski, M. (2019). Prawo do sądu administracyjnego. Standard międzynarodowy i konstytucyjny oraz jego realizacja. Warszawa: Wolters Kluwer. 
Nita, A. (2018). Przedawnienie jako instrument kształtowania pewności pozycji prawnej podatnika. W: A. Kaźmierczyk, A. Franczak, red., Zasada pewności w prawie podatkowym. Warszawa: Wolters Kluwer.

Raport: Instrumentalne wszczynanie postępowań karnych skarbowych w trakcie postępowań kontrolnych i podatkowych - analiza praktyki stosowania art. $70 \S 6$ pkt 1 Ordynacji Podatkowej. Raport podsumowujący wyniki badania danych uzyskanych w trybie dostępu doinformacji publicznej, https://https://gww.pl/media/publications/pdfs/Raport-podsumowuj\%C4\%85cyKKS-GWW.pdf [dostęp 7.06.2021].

Strzelec, D. (2020). O potrzebie sądowej kontroli skuteczności zawieszenia biegu terminu przedawnienia z uwagi na wszczęcie postępowania karnego skarbowego. Przegląd Podatkowy, 11.

Uchwała pełnej Izby Finansowej NSA z 29.09.2014 r., II FPS 4/13.

Ustawa z dnia 29 sierpnia 1997 r. Ordynacja Podatkowa, Dz.U. 2020, poz. 1325 ze zm.

Ustawa z dnia 25 lipca 2002 r. Prawo o ustroju sądów administracyjnych, Dz.U. 2017, poz. 2188 ze zm.

Ustawa z dnia 30 sierpnia 2002 r. Prawo o postępowaniu przed sądami administracyjnymi, Dz.U. 2019, poz. 2325 ze zm.

Wyrok NSA z 26.09.2011 r., II FSK 513/10, POP 2012, Nr 1, poz. 1.

Wyrok NSA z 24.11.2016 r., II FSK 1488/15.

Wyrok NSA z dnia 30.07.2020 r., I FSK 128/20.

Wyrok TSUE w sprawie C-617/10 Åkerberg Fransson przeciwko Åklagaren (ECLI:EU:C:2013:105).

Wyrok WSA we Wrocławiu z dnia 22 lipca 2019 r., I SA/Wr 365/19.

Wyrok ETPC w sprawie 6903/75 Deweer przeciwko Belgii (ECLI:CE:ECHR:1980:0227JUD000690375).

Wyrok ETPC w sprawie0541/08, 50571/08, 50573/08 i 40351/09 Ibrachim i inni przeciwko Zjednoczonemu Królestwu (ECLI:CE:ECHR:2016:0913JUD005054108).

Wyrok ETPC w sprawie 21980/04 Simeonovi przeciwko Bułgarii (ECLI:CE:ECHR:2017:0512JUD002198004).

Wyrok ETPC w sprawie5100/71, 5101/71, 5102/71, 5354/72, 5370/72 Engel i inni przeciwko Niderlandom (ECLI:CE:ECHR:1976:1123JUD000510071).

[www1] https://rzecznikmsp.gov.p1/24-05-2021-nsa-na-wniosek-rzecznika-msp-sady-administracyjne-instrumentalnego-wszczynania-postepowan-karno-skarbowych/ [dostęp 2.06.2021]. 